\title{
Gene flow and population viscosity in Myrmica ants
}

\author{
PERTTU SEPPÄ* \& PEKKA PAMILO† \\ Department of Genetics, University of Helsinki, PO Box 17 (Arkadiankatu 7), FIN-00014 University of Helsinki, Finland \\ and + Department of Genetics, Uppsala University, Box 7003, S-750 07 Uppsala, Sweden
}

\begin{abstract}
The amount of gene flow and population viscosity were studied in two red ant species, Myrmica ruginodis and $M$. rubra. Differentiation between populations at the local scale (within the dispersal distance of individuals) and between localities further apart was estimated using Wright's $F$ statistics. Population viscosity was described using spatial autocorrelation of allele frequencies of nests. The differentiation patterns in the two species are clearly distinct, $F_{\mathrm{ST}}$ values being an order of magnitude larger in $M$. rubra (M. rubra: $F_{\mathrm{ST}}=0.205$ between sites within localities and 0.199 between localities; $M$. ruginodis: $F_{\mathrm{ST}}=0.027$ and 0.014 between sites within localities, 0.009 between localities). Thus, assuming the island model, much less gene flow occurs between neighbouring $M$. rubra than $M$. ruginodis sites. Allele frequencies of nests close to each other are positively autocorrelated in both species. This suggests that new nests are commonly founded close to the mother nest, most probably by division of existing nests. $M$. rubra forms large multinest societies, which dominate substantial areas, whereas such multinest colonies are rare in $M$. ruginodis.
\end{abstract}

Keywords: dispersal, gene flow, Myrmica nest budding, social insects, sociogenetic organization.

\section{Introduction}

Mutation, genetic drift and locally differing selection pressures are evolutionary factors leading to major genetic differences, and ultimately to speciation of isolated populations. Apart from these factors genetic differences may arise because of the founder effect. If local populations are founded by a small number of individuals, through bottlenecks, they may differ from their source populations because of chance (e.g. Nei, 1987). On the other hand, dispersal of individuals prior to reproduction may lead to gene flow, which is a powerful factor opposing differentiation. Generally a very small number of migrants is enough to prevent substantial differentiation among populations (Slatkin, 1987). Gene flow can be restricted because of subdivision of populations, where individuals move mainly within physically or otherwise separated subpopulations, or because of isolation-by-distance in a continuous population.

Social insects live in family units, colonies, where individuals are usually more related to each other than to randomly chosen individuals of the population (e.g.

*Correspondence.
Hölldobler \& Wilson, 1990). This adds another level to the studies of genetic differentiation in addition to the conventional geographical variation among separate populations or subpopulations. Genetic differentiation between colonies can be measured as genetic relatedness within colonies (genotypic correlation between colony members; Hamilton, 1972). Within-colony relatedness is a central element in the kin selection theory for the evolution of altruistic behaviour (Hamilton, 1964). Because of this most genetic studies of social insects have focused on intracolony genetics instead of differentiation at higher levels of social organization or between geographical areas.

There is a strong association between the sociogenetic organization of the colonies and means of dispersal of ants. Monogynous species (species with a single queen in each colony) generally take part in mating flights and found new colonies independently or by temporarily parasitizing colonies of alien species whereas in polygynous species (many queens in a colony) females often mate within or close to the mother colony and colonies are frequently founded by division of existing ones (Rosengren \& Pamilo, 1983; Keller, 1991). These differences in dispersal patterns 
lead to different expectations concerning the distribution of genetic variation. Monogyny associated with a mating flight should promote sufficient gene flow for a uniform distribution of allele frequencies over large areas. If polygynous colonies recruit their own daughters as new reproductives and polydomous (multi-nest) societies arise through budding, allele frequencies may cluster spatially, and the population become viscous. Budding and viscosity can, of course, be accompanied by long-distance dispersal of some sexuals, e.g. by males.

A pair of closely related red ant species, Myrmica ruginodis and $M$. rubra, provide a possibility to test whether the sociogenetic organization of populations is associated with gene flow (Pamilo \& Rosengren, 1984). Ecological and genetic studies have previously shown that the colony types (number of queens per colony, affinity of nests) vary both within and between Myrmica species (Elmes, 1975, 1980; Seppä, 1992; Elmes \& Keller, 1993; Pearson \& Raybould, 1993). In this paper differentiation is studied at three levels: between nests within a site, between sites within the potential dispersal distance of sexuals and between localities covering a large geographical area. The study is based on allozyme markers, which are generally regarded as selectively neutral markers in the genome unless contradicting information is presented (Chakraborty \& Leimar, 1987). No such information is available, and therefore selection is neglected as a force leading to genetic differences between populations and the results are interpreted merely to reflect the balance between gene flow and genetic drift.

\section{Materials and methods}

\section{Species studied}

The number of queens in Myrmica is a highly variable trait both within populations, between populations and between species. In this respect $M$. rubra and $M$. ruginodis represent the two ends of the spectrum: $M$. rubra usually has highly polygynous colonies whereas $M$. ruginodis is one of the most monogynous species of the genus. This distinction is, however, somewhat confused because of the the coexistence of two social forms of $M$. ruginodis. The larger macrogyna form tends to have monogynous colonies, the smaller microgyna being on average more polygynous (Elmes, 1975, 1980; Elmes \& Keller, 1993). The relative frequencies of the two forms cannot be estimated from the present data.

Mating flights in Myrmica are fairly local events and long-range dispersal is thought to be rare (Elmes \& Clarke, 1981; Elmes, 1991). If gene flow is restricted, genetic differentiation is expected between both $M$. ruginodis and $M$. rubra populations. Myrmica queens, including $M$. ruginodis and $M$. rubra, are typically adopted into existing colonies (Brian \& Brian, 1949, 1955; Elmes, 1975, 1980; Mizutani, 1981; Kasugai et al., 1983). Macrogyna queens of $M$. ruginodis, however, commonly found nests independently, either alone or in small groups (Brian \& Brian, 1949). Therefore there are slightly different expectations concerning population viscosity in the two species: colonies of $M$. rubra should be more polydomous and their populations more viscous compared with $M$. ruginodis.

\section{Samples}

In $M$. ruginodis genetic viscosity within a population was studied in Savero, Anjalankoski, S.E. Finland, where 52 nests were found and sampled within a $20 \times 20 \mathrm{~m}$ area. Differentiation of populations at a local scale was studied in two locations. Seven sites were sampled at Tvärminne zoological station, Hanko, S.W. Finland, and six in the vicinity of Hyytiälä forest research station, Juupajoki, Central Finland. The sample sites in Tvärminne were on different islands, separated by $250 \mathrm{~m}$ to $3 \mathrm{~km}$ within a $3 \times 3 \mathrm{~km}$ area, which makes this population an ideal model of a subdivided population. The sites in Hyytiälä represent somewhat arbitrarily selected parts of a continuous population. The sites were located within a $6 \times 6 \mathrm{~km}$ area and were separated by $500 \mathrm{~m}$ to $8 \mathrm{~km}$. Genetic differentiation at a larger geographical scale was studied in an area covering most of the range of the species in Finland. Thirteen localities (including Savero, Tvärminne and Hyytiälä) were sampled (see Figs $1-3$ and Table 1 for populations studied and sample sizes).

In $M$. rubra viscosity was studied within one site (TVP) at Tvärminne zoological station; 25 nests were found and sampled within a $10 \times 20 \mathrm{~m}$ area. Five sites separated by $100 \mathrm{~m}$ to $1 \mathrm{~km}$ were sampled in Tvärminne. The sites were linearly located; three of them were on the mainland and two on different islands. Finally, even localities (including Tvärminne) were sampled (see Figs 1-3 and Table 1 for populations studied and sample sizes).

$M$. ruginodis is a very common red ant species in the Palaearctic (Elmes \& Clarke, 1981) and populations in boreal forests are often dense and continuous. Sampling covered large areas up to several square kilometers and, in Tvärminne, whole islands. Habitat requirements of $M$. rubra are more strict and populations are usually well-defined. Sampling was consequently carried out within smaller areas. From each population a considerable number of colonies was selected (see Table 1, for 


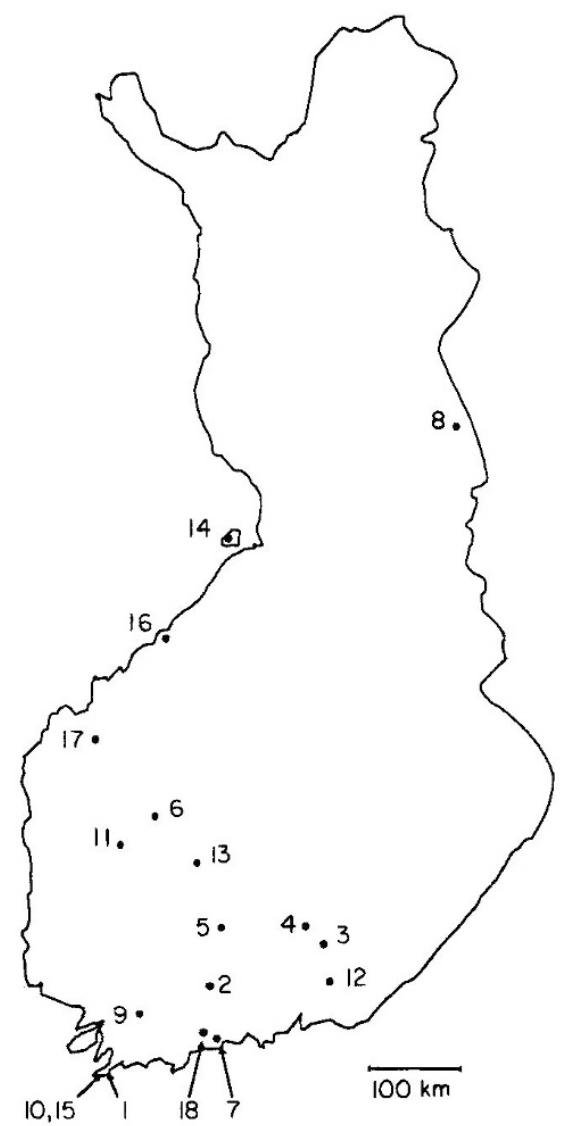

Fig. 1 Location of the populations of Myrmica sampled in Finland.

sample sizes) and a small number of workers was sampled. The total number of colonies sampled was 824 in $M$. ruginodis and 227 in $M$. rubra; 6-20 workers from each colony in both species were analysed fresh or stored in $-70^{\circ} \mathrm{C}$ up to several months before analysis. The number of workers analysed was generally equal per nest within a population, but varied between populations and species.

\section{Electrophoresis}

Worker samples were analysed using standard horizontal electrophoretic systems described in more detail by Seppä (1992) and Pamilo (1993). The loci studied in $M$. ruginodis were $a$-glycerophosphate dehydrogenase-1 ( $\alpha G p d h-1$, E.C. number: 1.1.1.8), phosphoglycerate kinase $(P g k, 2.7 .2 .3)$ and esterase-2 (Est-2, 3.1.1.1, substrate: 4-methylumbelliferryl acetate). In the Savero population peptidase (Pep, 3.4.*.*, substrate: glycyl-L-leucine) was also studied. For $M$. rubra Est-2, Pgk, Pep and glutamate-oxaloacetate transaminase-1 (Got-1, 2.6.1.1) were examined.

\section{Estimation of genetic differentiation}

Genetic differentiation within subdivided populations is commonly described using Wright's $F$-statistics, where the standardized allele frequency variance among populations, $F_{\mathrm{ST}}$, describes the amount of genetic differentiation between subpopulations (Wright, 1951). $F_{\mathrm{ST}}$ was estimated using the method of Cockerham (1969, 1973), which corrects for unequal sample sizes. Standard errors of the estimates were obtained by jackknifing over populations and loci and deviation from zero was determined using these values. The $F_{\mathrm{ST}}$ calculations were performed using B. Weir's DIPLOID.FOR computer program (Weir, 1990).

The island model of migration assumes that gene flow happens from any subpopulation to any subpopulation with the same probability and at an equilibrium of gene flow and genetic drift, $F_{\mathrm{ST}}$ is a function of the effective population size $\left(N_{\mathrm{e}}\right)$ and migration rate $(m): F_{\mathrm{ST}}=1 /\left(1+4 N_{\mathrm{e}} m\right)$ (Wright, 1943). $F_{\mathrm{ST}}$ can be estimated from genetic data and the number of migrating individuals $\left(N_{\mathrm{e}} m\right)$ can be obtained. If $F_{\mathrm{ST}}>0.2$, there is said to be significant genetic differentiation between populations (Wright, 1943; Endler, 1977; Slatkin, 1987).

Population viscosity within the sites studied was characterized with a spatial autocorrelation method. The spatial autocorrelation coefficient of the variable, Moran's $I$, is obtained by correlating the values of the variable (e.g. allele frequencies) in the contiguous pairs of nests (Sokal \& Oden, 1978). A pair of nests is contiguous if the nests are, for instance, connected with a Gabriel network. Two nests, A and B, are Gabrielconnected if all other nests are outside the circle whose diameter is the line A-B (Gabriel \& Sokal, 1969). Another way to calculate the autocorrelation coefficient is to use a distance-connected correlogram, where correlation is calculated separately for all the pairs of nests belonging to a given distance class (Sokal \& Wartenberg, 1983). Values of the variables are positively autocorrelated if the coefficient $I$ is larger than the random expectation, which is slightly negative (Sokal \& Oden, 1978).

In this work Moran's autocorrelation coefficient $I$ was calculated for both Gabriel-connected and distance-connected nests. In order to study the extent of the viscosity several distance units were used in the distance-connected correlogram: 2, 3, 4, 5, 7 and $10 \mathrm{~m}$ (calculated in a cumulative way, the larger distance units including the smaller ones). The autocorrelation coefficient was calculated for all the alleles in the datasets as well as for the factor scores of the nests associated with the principal components of the complete set of alleles (Crozier et al., 1984). 
Fig. 2 Location of the Myrmica sampling sites at the Trärminne Zoological Station (*).

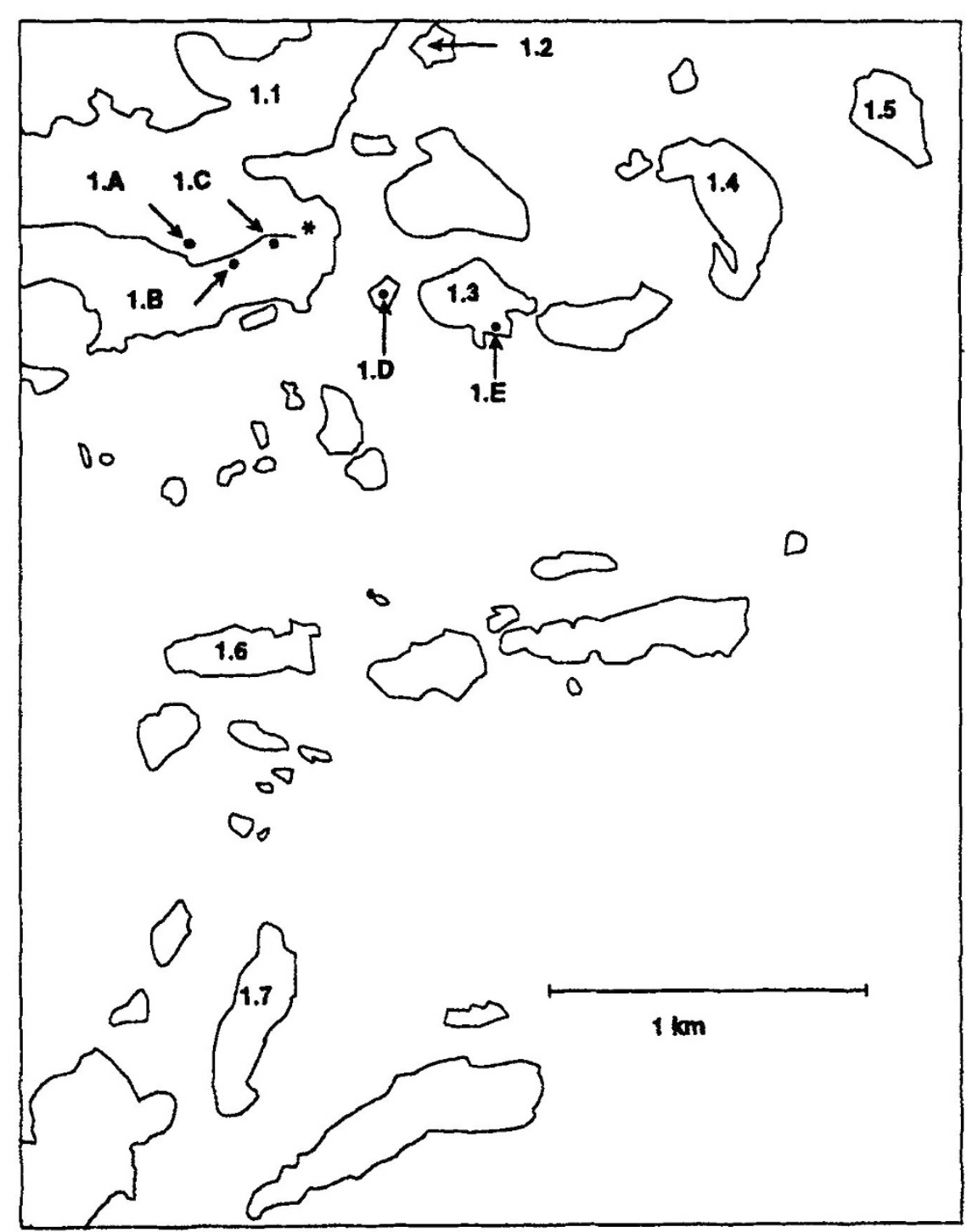

\section{Results}

All the loci studied, except $a G p d h-1$ in $M$. ruginodis, were biallelic systems. In populations 1.1-1.7 and 2-7 (Table 2) up to three alleles were detected in $\alpha$ Gpdh-1, two slow ones (91 and 81 ) besides the common one $(100)$. Later a fourth allele (fast, $F$ ) could be separated from the common one. Because $F$ was most probably missed in the first populations and combined with 100 , the alleles were joined also in the rest of the populations before the analyses. Furthermore, because 81 was always very rare, it was combined with 91 . Allele frequencies were calculated weighting colonies equally irrespective of the number of individuals studied (Table 2).

\section{Differentiation between sites and localities}

In both species $F_{\mathrm{ST}}$ was estimated separately at two levels, between sites within Tvärminne and Hyytiälä areas and between localities. The estimates for individual loci and means over loci are presented in Table 3. Differentiation among $M$. rubra sites in Tvärminne is strong and significantly different from zero $\left(F_{\mathrm{ST}}=0.205 \pm 0.039, t_{4}=5.26,0.01>P>0.001\right)$ and the estimate among localities is of the same magnitude $\left(F_{\mathrm{ST}}=0.199 \pm 0.062, t_{7}=3.21,0.05>P>0.01\right)$.

In $M$. ruginodis, there is less differentiation among sites $\left(F_{\mathrm{ST}}=0.027 \pm 0.014\right.$ in Tvärminne and $0.014 \pm 0.007$ in Hyytiälä). These values are not significantly different from zero $\left(t_{6}=1.93, t_{12}=2.0\right.$, respectively). Differentiation among $M$. ruginodis localities is 


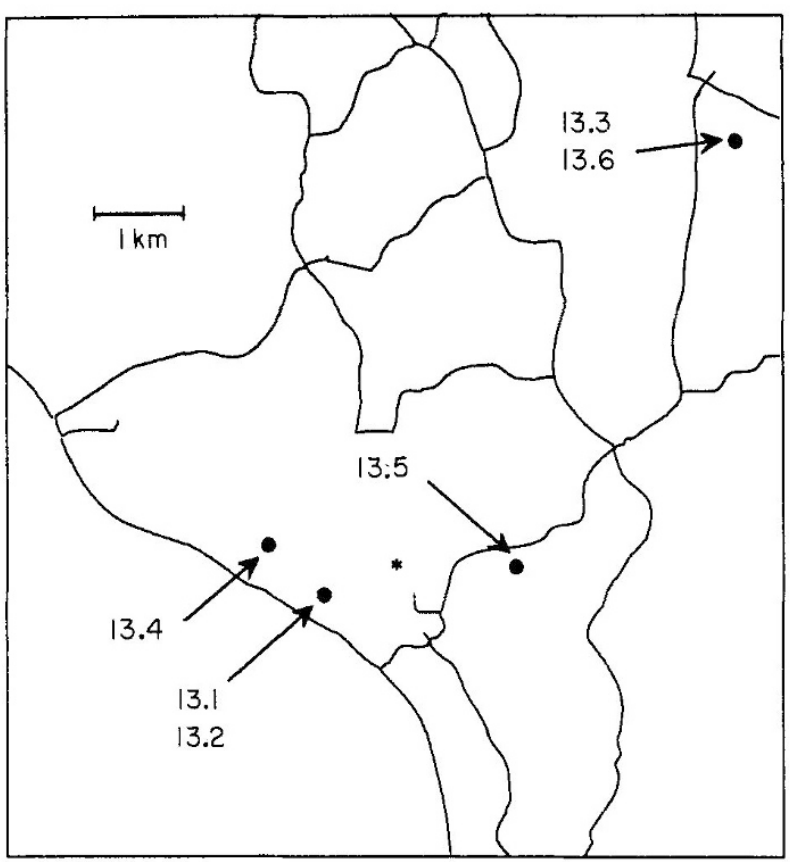

Fig. 3 Location of the Myrmica sampling sites in the vicinity of Hyytiälä Forest Research Station (*).

significant, although the $F_{\mathrm{ST}}$ estimate is even smaller $\left\langle F_{\mathrm{ST}}=0.009 \pm 0.000\right)$. Assuming the island model, the estimates of the number of migrating individuals between sites, $N_{\mathrm{e}} m$, are generally an order of magnitude larger in $M$. ruginodis than in $M$. rubra (Table 3).

\section{Viscosity of populations}

Moran's autocorrelation coefficients $I$ are shown in Table 4 for individual alleles and factor scores of principal components (PCA). Because one of the aims of this work was to study the extent of viscosity within populations, only coefficients of the shortest distances are given (Table 4).

In $M$. ruginodis the first two factors of principal components explain 42 per cent and 21 per cent of the total variation. However, there is very little covariance among loci in this dataset and the first two factors describe mainly variation in two $\alpha G p d h$ alleles, 100 and $F$, respectively. Hence $P C A 1$ and $P C A 2$ give a similar result concerning autocorrelation as these alleles. The most polymorphic alleles contain most information, therefore the allele 100 of $\alpha G p d h-1$ and $P C A 1$ give the most reliable information about population viscosity. According to them both Gabrielconnected nests and nests up to $4 \mathrm{~m}$ from each other are positively autocorrelated. PCA2 and the rest of the alleles show similar patterns, although the extent of the positive autocorrelation coefficients varies.
Table 1 Populations of Myrmica studied and sample sizes $(N)$ as the number of colonies

\begin{tabular}{lrlr}
\hline Locality & $N$ & $N$ \\
\hline M. ruginodis & & Locality & \\
1 Tvärminne & 217 & 1 Tvärminne & 97 \\
2 Oitti & 35 & 9 Pusula & 25 \\
3 Verla & 33 & 14 Hailuto & 8 \\
4 Jaala & 41 & 15 Täktbukten & 19 \\
5 Lammi & 24 & 16 Letto & 23 \\
6 Virrat & 36 & 17 Tenkkula & 27 \\
7 Helsinki & 13 & 18 Gallträsk & 28 \\
8 Oulanka & 26 & & \\
9 Pusula & 9 & & \\
10 Täktom & 113 & & \\
11 Seitseminen & 65 & & \\
12 Savero & 52 & &
\end{tabular}

Sites in the Tvärminne area

$\begin{array}{lll}\text { 1.1 Tvärminne O } & 36 \\ \text { 1.2 Kvarnskär } & 17 \\ \text { 1.3 Halsholmen } & 38 \\ \text { 1.4 Brännskär } & 25 \\ \text { 1.5 Skomakarskär } & 33 \\ \text { 1.6 Kalvholmen } & 25 \\ \text { 1.7 Mellanskär } & 43\end{array}$

$\begin{array}{ll}\text { 1.A Niitty } & 21 \\ \text { 1.B Pelto } & 26 \\ \text { 1.C Kasvimaa } & 12 \\ \text { 1.D Porsgrundet } & 19 \\ \text { 1.E Halsholmen } & 19\end{array}$

Sites in the Hyytiälä area

13.1 Ahvenkangas N 20

13.2 Ahvenkangas S 26

13.3 Kulo 22

13.4 Susimäki $\quad 34$

13.5 Hyytiälä 29

13.6 Naurisvuori 29

There were two exceptions from the general pattern in $M$. ruginodis. Firstly, the autocorrelation coefficient of the Gabriel-connected nests in Pep was slightly smaller than the expected. However, the coefficient was larger than the expected in the distance class $0-2 \mathrm{~m}$. This discrepancy probably arises because in some cases Gabriel-connected nests are further apart than 2 m. A more serious problem is that Est shows highly significant negative spatial autocorrelation consistently throughout the analysis. In other genetic analyses of Est $\left(F_{\mathrm{ST}^{-}}\right.$-analysis in this work and relatedness calculations elsewhere; Seppä, 1992, 1994 and unpublished data), the Est locus gives results similar to other loci and there has been no reason to suspect that Est is not a selectively neutral marker locus. The reason for the deviating result for Est remains unknown.

$M$. rubra shows a similar absence of covariance among loci and the first principal component factor 
Table 2 Allele frequencies of the populations. In Myrmica ruginodis populations 1.1-1.7 and 2-7 allele $F$ of $a G p d h-1$ could not be separated from allele 100 and their frequencies are pooled into 100

\begin{tabular}{|c|c|c|c|c|c|c|c|c|}
\hline \multicolumn{5}{|c|}{ M. ruginodis } & \multicolumn{2}{|c|}{$P g k$} & \multicolumn{2}{|c|}{ Est -2} \\
\hline & 100 & $F$ & 91 & 81 & 100 & $F$ & 100 & $S$ \\
\hline 1.1 & 0.737 & - & 0.220 & 0.044 & 0.886 & 0.114 & 0.644 & 0.356 \\
\hline 1.2 & 0.759 & - & 0.241 & - & 0.826 & 0.174 & 0.885 & 0.115 \\
\hline 1.3 & 0.786 & - & 0.214 & - & 0.895 & 0.105 & 0.811 & 0.189 \\
\hline 1.4 & 0.644 & - & 0.329 & 0.027 & 0.876 & 0.124 & 0.842 & 0.158 \\
\hline 1.5 & 0.766 & - & 0.210 & 0.023 & 0.966 & 0.034 & 0.647 & 0.353 \\
\hline 1.6 & 0.740 & - & 0.245 & 0.015 & 0.957 & 0.043 & 0.762 & 0.238 \\
\hline 1.7 & 0.743 & - & 0.213 & 0.044 & 0.791 & 0.209 & 0.647 & 0.353 \\
\hline 2 & 0.673 & - & 0.325 & 0.003 & 0.857 & 0.143 & 0.696 & 0.304 \\
\hline 3 & 0.744 & - & 0.250 & 0.006 & 0.805 & 0.195 & 0.695 & 0.305 \\
\hline 4 & 0.678 & - & 0.297 & 0.025 & 0.836 & 0.164 & 0.624 & 0.376 \\
\hline 5 & 0.743 & - & 0.244 & 0.013 & 0.813 & 0.187 & 0.777 & 0.223 \\
\hline 6 & 0.667 & - & 0.320 & 0.013 & 0.753 & 0.247 & 0.743 & 0.257 \\
\hline 7 & 0.477 & - & 0.523 & - & 0.785 & 0.215 & 0.801 & 0.199 \\
\hline 8 & 0.494 & 0.146 & 0.360 & - & 0.794 & 0.206 & 0.702 & 0.298 \\
\hline 9 & 0.474 & 0.226 & 0.300 & - & 0.662 & 0.338 & 0.646 & 0.354 \\
\hline 10 & 0.557 & 0.161 & 0.272 & 0.009 & 0.800 & 0.200 & 0.690 & 0.310 \\
\hline 11 & 0.510 & 0.154 & 0.300 & 0.034 & 0.743 & 0.267 & 0.691 & 0.309 \\
\hline 12 & 0.493 & 0.200 & 0.286 & 0.021 & 0.833 & 0.167 & 0.740 & 0.260 \\
\hline 13.1 & 0.610 & 0.122 & 0.255 & 0.013 & 0.782 & 0.218 & 0.493 & 0.507 \\
\hline 13.2 & 0.600 & 0.082 & 0.318 & - & 0.790 & 0.210 & 0.669 & 0.331 \\
\hline 13.3 & 0.609 & 0.088 & 0.253 & 0.049 & 0.855 & 0.145 & 0.669 & 0.331 \\
\hline 13.4 & 0.543 & 0.106 & 0.327 & 0.024 & 0.874 & 0.126 & 0.666 & 0.334 \\
\hline 13.5 & 0.497 & 0.108 & 0.365 & 0.030 & 0.771 & 0.229 & 0.751 & 0.249 \\
\hline 13.6 & 0.502 & 0.140 & 0.335 & 0.022 & 0.793 & 0.207 & 0.657 & 0.343 \\
\hline
\end{tabular}

\begin{tabular}{|c|c|c|c|c|c|c|c|c|}
\hline \multirow[t]{2}{*}{ M. rubra } & \multicolumn{2}{|c|}{ Est-2 } & \multicolumn{2}{|c|}{$P g k$} & \multicolumn{2}{|c|}{ Pep } & \multicolumn{2}{|c|}{ Got-1 } \\
\hline & 100 & $F$ & 100 & $S$ & 100 & $F$ & 100 & $F$ \\
\hline 1.A & 0.618 & 0.382 & 0.843 & 0.157 & 0.863 & 0.137 & 0.671 & 0.329 \\
\hline 1. $\mathrm{B}$ & 0.986 & 0.014 & 0.827 & 0.173 & 0.470 & 0.530 & 0.991 & 0.009 \\
\hline 1.C & 0.457 & 0.543 & 1 & - & 0.920 & 0.080 & 0.983 & 0.017 \\
\hline 1.D & 0.993 & 0.007 & 1 & - & 0.802 & 0.198 & 0.987 & 0.013 \\
\hline 1.E & 0.629 & 0.371 & 0.989 & 0.011 & 0.632 & 0.368 & 0.981 & 0.019 \\
\hline 9 & 0.422 & 0.578 & 1 & - & 0.897 & 0.103 & 0.862 & 0.138 \\
\hline 19 & 0.247 & 0.753 & 1 & - & 0.671 & 0.329 & 0.914 & 0.086 \\
\hline 20 & 0.801 & 0.199 & 0.947 & 0.053 & 0.782 & 0.218 & 0.914 & 0.086 \\
\hline 21 & 0.732 & 0.268 & 0.972 & 0.028 & 0.822 & 0.178 & 0.767 & 0.233 \\
\hline 22 & 0.605 & 0.395 & 0.809 & 0.191 & 1 & - & 0.864 & 0.136 \\
\hline 23 & 0.882 & 0.118 & 1 & - & 0.998 & 0.002 & 0.998 & 0.002 \\
\hline
\end{tabular}

explains 67 per cent of the total variation, which almost exclusively arises from variation in Pep. PCAl and Pep show highly positive spatial autocorrelation both between Gabriel-connected nests and between nests up to $7 \mathrm{~m}$ from each other. The other variable locus, $P g k$, gives a similar result.

\section{Discussion}

\section{Gene flow and geographical differentiation}

$M$. ruginodis and $M$. rubra are clearly distinctive in their patterns of gene flow. $M$. rubra populations show extremely strong differentiation. The estimate of $F_{\mathrm{ST}}$ 
Table $3 F_{\text {ST }}$ estimates $( \pm \mathrm{SE}$ ) for individual loci, mean of loci and the consequent estimates of the number of migrating Myrmica individuals $\left(N_{\mathrm{e}} m\right)$ assuming the equilibrium of the island model

\begin{tabular}{lccc}
\hline Locus & Tvärminne & Hyytiälä & Whole data \\
\hline $\begin{array}{l}\text { M. ruginodis } \\
\alpha \text { Gpdh-1 }\end{array}$ & $0.007 \pm 0.009$ & $0.004 \pm 0.004$ & $0.009 \pm 0.004$ \\
Pgk & $0.035 \pm 0.020$ & $0.013 \pm 0.008$ & $0.010 \pm 0.005$ \\
Est & $0.043 \pm 0.012$ & $0.024 \pm 0.022$ & $0.010 \pm 0.007$ \\
Mean & $0.027 \pm 0.014$ & $0.014 \pm 0.007$ & $0.009 \pm 0.000$ \\
$N_{\mathrm{e}} m$ & 9.0 & 17.6 & \\
M. rubra & & & \\
Est -2 & $0.259 \pm 0.138$ & & $0.244 \pm 0.105$ \\
Pgk & $0.111 \pm 0.047$ & & $0.137 \pm 0.099$ \\
Pep & $0.158 \pm 0.078$ & & $0.139 \pm 0.067$ \\
Got-1 & $0.263 \pm 0.218$ & & $0.073 \pm 0.059$ \\
Mean & $0.205 \pm 0.039$ & & $0.199 \pm 0.062$ \\
$N_{\mathrm{e}} m$ & 1.0 & & \\
\hline
\end{tabular}

was 0.2 both among sites and localities, a figure which has been interpreted to indicate significant differentiation between populations (Wright, 1943; Endler, 1977; Slatkin, 1987). This differentiation can be interpreted in terms of migration among the sites in the Tvärminne population, and the estimate of migrants, $N_{\mathrm{e}} m$, is one per generation. Hence the populations were rather isolated from each other, although they were separated by only $1 \mathrm{~km}$ at most.

The amount of differentiation between $M$. ruginodis populations was much smaller and the estimates of $N_{\mathrm{e}} m$ were generally more than an order of magnitude larger. In contrast to $M$. rubra, dispersal of $M$. ruginodis sexuals apparently leads to gene flow between separate subpopulations. The higher $F_{\mathrm{ST}}$ value in Tvarminne compared with the continuous Hyytiälä population suggests that distances between the islands in Tvärminne form a dispersal barrier of some kind.

Elmes \& Clarke (1981) failed to find any substantial morphological differentiation in $M$. ruginodis workers between nests or between higher levels of isolation. This study shows a similar pattern at the genetic level and supports the conclusion of genetic homogeneity within the species. Elmes \& Clarke (1981) further suggested that the recent expansion of the species to its present range has caused the lack of variation. Alternatively, homogeneity can be maintained by continuous gene flow between populations.

\section{Population viscosity and colony founding}

Based on autocorrelation coefficients, populations are viscous in both species suggesting limited dispersal of females. A fraction of Myrmica females apparently do not disperse but stay in the mother colony and found new nests through budding. This is supported by the fact that coexisting queens are usually related in Myrmica (Pearson \& Raybould, 1993; Seppä, 1994 and unpublished data), which in practice means that colonies do recruit their own daughters as new queens. Limited dispersal is probably mostly associated with the establishment of polydomous colonies by the splitting of existing polygynous colonies, but females could also found new nests independently in the vicinity of the parental nest. Whether the groups of nests are interconnected (polycalic) was not studied.

The mainly monogynous macrogyna form of $M$. ruginodis has previously been considered also as monodomous with independent colony founding (Brian \& Brian, 1949, 1955). In contrast, the more polygynous microgyna form is known to be polydomous and to found new colonies by division of existing ones (Brian \& Brian, 1949, 1955; Kasugai et al., 1983). The population studied in our work (Savero) is a mixture of the two forms and there are several polydomous colonies of both forms (P. Seppä, unpublished data).

In order to maintain substantial genetic differences, as observed between $M$. rubra sites, gene flow must be very restricted. It is possible that sexuals do not disperse from one site to another, but it is more probable that they do disperse but are actively prevented from joining the gene pool of an alien colony. This should restrict the gene flow by females, but some gene flow would be expected to be carried by males. Restricted gene flow is expected to be associated with matings between members of the same colony.

We have interpreted the $F_{\mathrm{ST}}$ estimates as reflecting the numbers of migrating individuals. However, it is not at all certain that the study population of $M$. rubra fulfils the underlying assumptions (island model, equilibrium between gene flow and drift) and the pattern of genetic differentiation can largely reflect the founding history of the subpopulations. Differences between sites agree with the interpretation that the populations are founded by very few individuals. After a successful colonization $M$. rubra colonies become polygynous and polydomous and seem to be able to dominate large areas just as some mound-building Formica ants do (the 'rare patch dominators', Rosengren \& Pamilo, 1983). Genetic differences between nearby $M$. rubra subpopulations are in fact as large as differences between colonies in the more monodomous $M$. ruginodis. 


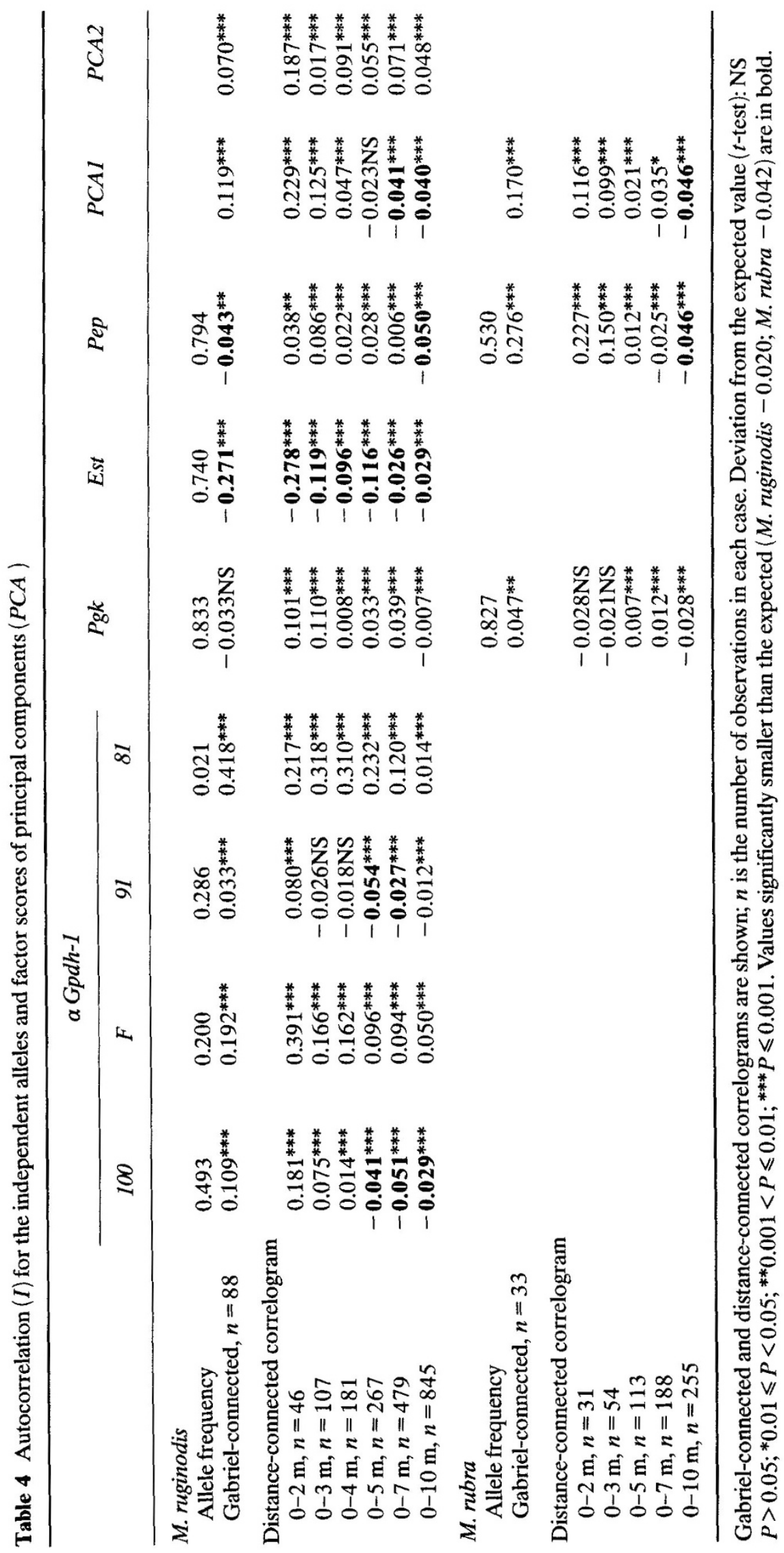




\section{Gene flow, population viscosity and sociogenetic organization}

The results from $M$. ruginodis and $M$. rubra generally agree with and strengthen the pattern arising from similar studies. Formica truncorum has two population types. One resembles $M$. ruginodis and has only monogynous colonies the other has polygynous colonies and resembles $M$. rubra (Sundström, 1993). As in $M$. ruginodis and $M$. rubra, the amount of gene flow between local populations is strikingly different in these two types $\left(F_{\mathrm{ST}}=0.030\right.$ and 0.190 , respectively; Sundström, 1993). There are no other good comparisons available, but our results can also be compared with some single species studies. Differentiation within a subdivided population is less in $M$. ruginodis $\left(F_{\mathrm{ST}}=0.027\right)$ than in $F$. exsecta and $F$. fusca on the same islands $\left\langle F_{\mathrm{ST}}=0.090\right.$ and 0.074 , respectively; Pamilo, 1983). Differentiation is also less between sampling sites within a continuous population in $M$. ruginodis $\left(F_{\mathrm{ST}}=0.014\right)$ than in smaller continous areas in $F$. transkaucasica and $F$. sanguinea $\left(F_{\mathrm{ST}}=0.072\right.$ and 0.046 , respectively; Pamilo, 1983). Differentiation has not been studied in highly polygynous and polydomous ants, but our unpublished results in $F$. aquilonia show patterns similar to $M$. rubra and the polygynous $F$. truncorum. These results suggest that polydomous colonies in general can have little gene flow.

Population viscosity, or genetic similarity of closely located nests within a population, most probably results from nest budding and polydomy. Viscosity is shown by positive autocorrelation of closely located nests in $M$. ruginodis and $M$. rubra. Similar positive values of autocorrelation over short distances have been found in F. sanguinea (Pamilo, 1983) and Rhytidoponera sp. 12 (Crozier et al., 1984). Viscosity has also been found in polydomous populations of $F$. exsecta (Pamilo \& Rosengren, 1984) and in Lasius neglectus (Boomsma et al., 1990), although detected with other methods. On the contrary, no short-distance autocorrelation was found in weakly polygynous $F$. fusca and $F$. transkaucasica. Their colonies are probably monodomous, although allele frequency differences among subpopulations and different parts of a continuous population suggested restricted dispersal (Pamilo, 1983).

Finally, based on RFLP polymorphism of mitochondrial DNA, Leptothorax acervorum nests having a common origin have been shown to be clustered. If the nests share the same genotype (haplotype), there is no doubt about the common maternal ancestor, because dispersing males cannot dilute the genetic composition of the maternally inherited mtDNA in daughter nests. This shows that dispersal of queens is restricted in $L$. acervorum and nest founding is most probably dependent on budding (Stille \& Stille, 1993).

In conclusion, $M$. ruginodis and $M$. rubra fulfil rather well the expectations of gene flow based on dispersal, sociogenetic organization and mode of nest founding outlined above. Both species are facultatively polygynous with limited dispersal during mating flights. This results in significant genetic differentiation between populations in $M$. rubra and in slight differentiation in $M$. ruginodis. New nests of the highly polygynous $M$. rubra are commonly started by budding from existing ones and colonies develop into large polydomous entities in suitable habitats. Once a polydomous colony has been estabilished, gene flow at least by females is restricted and alien sexuals do not breed in the colonies. $M$. ruginodis employs a mixed strategy of dispersal and nest founding. Most of the colonies are monodomous, but a few polydomous ones can be found. The former colonies must have been founded independently by dispersing queens whereas the latter group also reproduces by budding.

\section{Acknowledgements}

We thank Risto Väinölä and Jouni Vainio for their help in the data analysis, and Kirsi Vainio, Päivi Tuominen, Laura Walin and Cia Olsson for skilful technical assistance. This manuscript has been improved by comments of Koos Boomsma, Rainer Rosengren, Lotta Sundström and anonymous referees. This work was supported by the Finnish and Swedish Natural Sciences Research Council.

\section{References}

BOOMSMA, J. J., BROUWER, A. H. AND VAN LOON, A. J. 1990. A new polygynous Lasius species (Hymenoptera: Formicidae) from Central Europe. II. Allozymatic confirmation of species status and social structure. Insectes Sociaux, 37, 363-375.

BRIAN, M. V. AND BRIAN, A. D. 1949. Observations on the taxonomy of the ants Myrmica rubra L. and $M$. laevinodis Nylander (Hymenoptera: Formicidae). Trans, R. Ent. Soc. London, 100, 393-409.

BRIAN, M. V. AND BRIAN, A. D. 1955 . On the two forms macrogyna and microgyna of the ant Myrmica rubra L. Evolution, 9, 280-290.

CHAKRABORTY, R. AND LEIMAR, O. 1987. Genetic variation within a subdivided population. In: Ryman, N. and Utter, F. (eds) Population Genetics and Fishery Management, pp. 89-120. University of Washington, Seattle.

COCKERHAM, C. C. 1969. Variance of gene frequencies. Evolution, 23, 72-84.

COCKERHAM, C. C. 1973. Analyses of gene frequencies. Genetics, 74, 679-700. 
CROZIER, R. H., PAMILO, P. AND CROZIER, Y. C. 1984. Relatedness and microgeographic genetic variation in Rhytidoponera mayri, an Australian arid-zone ant. Behav. Ecol. Sociobiol., 15, 143-150.

Elmes, G. w. 1975. Population Studies on the Genus Myrmica (Hymenoptera, Formicidae), with Special Reference to Southern England. Ph.D. Thesis, University of London.

ELMES, G. W. 1980. Queen numbers in colonies of the ants of the genus Myrmica. Insectes Sociaux, 27, 43-60.

ELMES, G. W. 1991. Mating strategy and isolation between the two forms, macrogyna and microgyna, of Myrmica ruginodis (Hym. Formicidae). Ecol. Entomol., 16, 411-423.

ELMES, G. W. AND ClARKE, R. T. 1981. A biometric investigation of variation in workers of Myrmica ruginodis Nylander. In: Howse P. E. and Clément J.-L. (eds) Biosystematics of Social Insects, pp. 121-140. Academic Press, New York, London.

ELMES, G. W. AND KELLER, L. 1993. Distribution and ecology of queen number in ants of the genus Myrmica. In: Keller, L. (ed.) Queen Number and Sociality in Insects, pp. 294-307. Oxford University Press, Oxford.

ENDLER, J. 1977. Geographic Variation, Speciation and Clines. Princeton University Press, Princeton.

GABRIEL, K. R. AND SOKAL, R. R. 1969. A new statistical approach to geographic variation analysis. Syst. Zool., 18, 259-270.

HAMILTON, w. D. 1964. The genetic evolution of social behavior. J. Theor. Biol., 7, 1-52.

HAMILTON, w. D. 1972. Altruism and related phenomena, mainly in social insects. Ann. Rev. Ecol. Syst., 3, 193-232.

HÖlLDOBLER, B. AND WILSON, E. O. 1990. The Ants, pp. 187-188. Springer, Berlin.

KASUGAI, M., TAKEDA, S. AND SAKuRAI, H. 1983. Some observations on the microgyne form of ant Myrmica ruginodis Nylander (Hymenoptera, Formicidae) in Sapporo. Kontyo, 51, 73-79.

KELLER, L. 1991. Queen number, mode of colony founding and queen reproductive success in ants (Hymenoptera Formicidae). Ethol. Ecol. Evol., 3, 307-316.

MIZUTANI, A. 1981. On the two forms of the ant Myrmica ruginodis Nylander (Hymenoptera, Formicidae) from Sapporo and its vicinity. Jap J. Ecol., 31, 131-137.

NEI, M. 1987. Molecular Evolutionary Genetics. Columbia University Press, New York.
PAMILO, P. 1983. Genetic differentiation within subdivided populations of Formica ants. Evolution, 37, 1010-1022.

PAMILO, P. 1993. Polyandry and allele frequency differences between the sexes in the ant Formica aquilonia. Heredity, 70, 472-480.

PAMILO, P. AND ROSENGREN, R. 1984. Evolution of nesting strategies of ants: genetic evidence from different population types of Formica ants. Biol. J. Linn. Soc., 21, 331-348.

PEARSON, B. AND RAYBOULD, A. F. 1993. The effects of sampling and nest structure on relatedness in $M$. rubra populations (Hymenoptera: Formicidae). Sociobiology, 21, 209-216.

ROSENGREN, R. AND PAMILO, P. 1983. The evolution of polygyny and polydomy in mound-building Formica ants. Acta Entomol. Fennica, 42, 65-77.

SEPPÄ, P. 1992. Genetic relatedness of worker nestmates in Myrmica ruginodis (Hymenoptera: Formicidae) populations. Behav. Ecol. Sociobiol., 30, 253-260.

SEPPÄ, Р. 1994. Sociogenetic organization of the ants Myrmica ruginodis and $M$. lobicornis: number, genetic relatedness and longevity of reproducing individuals. J. Evol. Biol., 7, 71-95.

SLATKIN, M. 1987. Gene flow and the geographic structure of natural populations. Science, 236, 787-792.

SOKAL, R. R. AND ODEN, N. L. 1978. Spatial autocorrelation in biology. 1. Methodology. Biol. J. Linn. Soc., 10, 199-228.

SOKAL, R. R. AND WARTENBERG, D. E. 1983. A test of spatial autocorrelation analysis using an isolation-by-distance model. Genetics, 105, 219-237.

STILLE, M. AND STILLE, B. 1993. Intrapopulation nestclusters of maternal mtDNA linages in the polygynous ant Leptothorax acervorum (Hymenoptera: Formicidae). Insect Mol. Biol., 1, 117-121.

SUNDSTROM, L. 1993. Genetical population structure and sociogenetic organization in Formica truncorum. Behav. Ecol. Sociobiol., 33, 345-354.

WEIR, B. S. 1990 . Intraspecific differentiation. In: Hillis, D. M. and Moritz, C. (eds) Molecular Systematics, pp. 373-410. Sinauer, Sunderland, MA.

WrIGHT, s. 1943. Isolation by distance. Genetics, 28, 114-138.

WRIGHT, s. 1951. The genetical structure of populations. Ann. Eugen., 15, 323-354.1. 